\title{
"The effect of the ownership structure on earnings management practices"
}

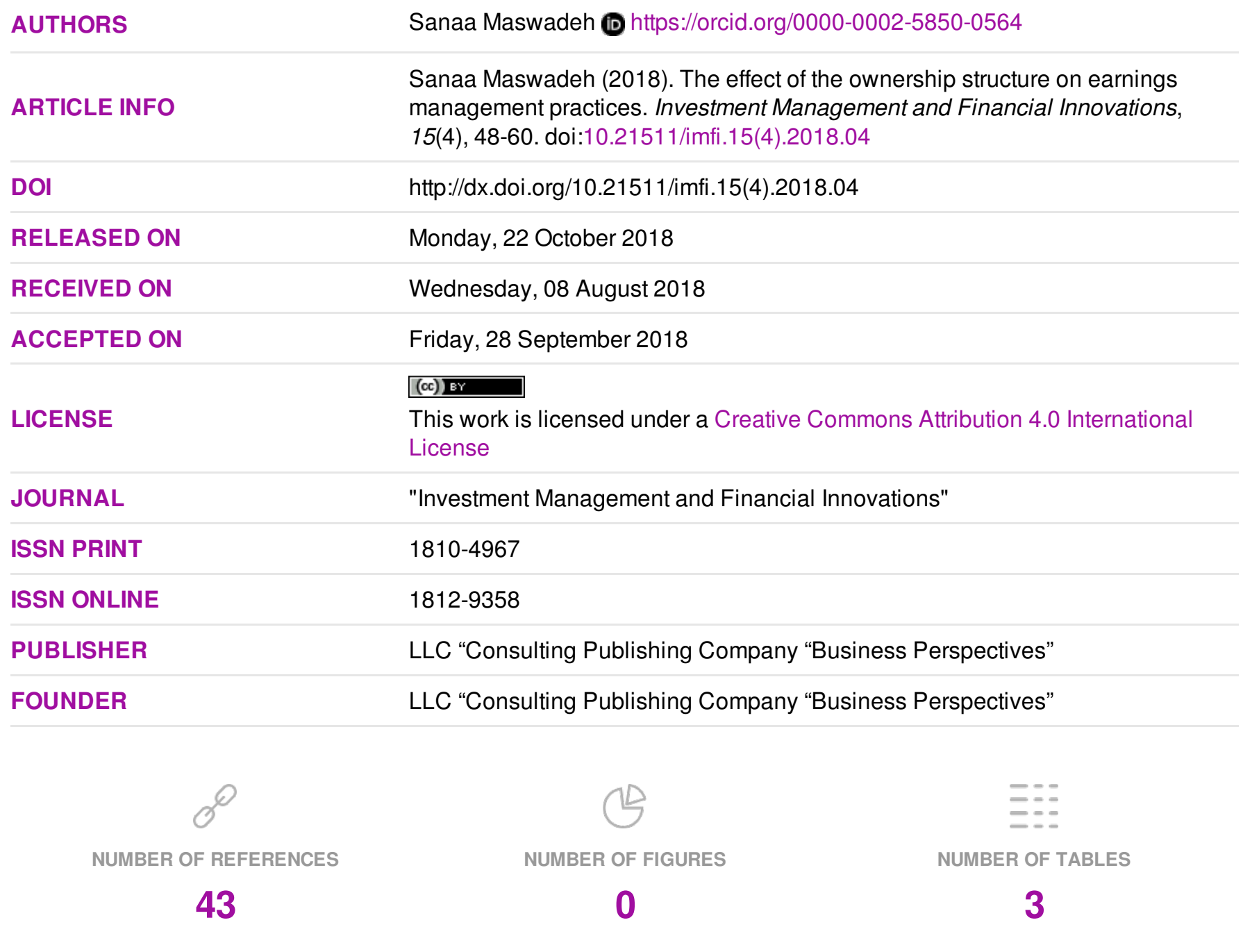

(C) The author(s) 2022. This publication is an open access article. 


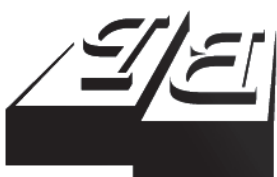

BUSINESS PERSPECTIVES

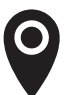

LLC "CPC "Business Perspectives" Hryhorii Skovoroda lane, 10, Sumy, 40022, Ukraine

www.businessperspectives.org

Received on: $8^{\text {th }}$ of August, 2018 Accepted on: $28^{\text {th }}$ of September, 2018

(C) Sanaa Maswadeh, 2018

Sanaa Maswadeh, Professor, Accounting Department, Middle East University, Amman, Jordan.

\section{THE EFFECT OF THE OWNERSHIP STRUCTURE ON EARNINGS MANAGEMENT PRACTICES}

\begin{abstract}
The objective of this study is to investigate the effect of the ownership structure, which includes concentration ownership, institutional ownership and foreign ownership in the light of the debt ratio and company size as controlling variables in limiting the earnings management practices of the Jordanian industrial companies for the period 2012-2016. The hypotheses of the study were tested using the multiple regression models. Among the most prominent findings of the study are: the explanatory factor (R2) for the independent and control variables accounts for $38 \%$ of the change in the earnings management of the Jordanian industrial companies, moreover, a significant effect of the concentration ownership was found in the limitation of earnings management practices; while, there was no significant influence of institutional ownership and foreign ownership on the earnings management practices in Jordanian industrial companies. Major limitation to this study is the only considered listed industrial Jordanian firms. Thus, the generalization of the results to other sectors and diverse economic conditions and regulations may be constrained. Finally, Jordanian policymaker reform policies motivate companies to increase their interest on concentration ownership structure, as the study showed the significant effect of the concentration ownership in the limitation of earnings management practice.
\end{abstract}

Keywords ownership structure, earnings management, Jordanian industrial companies

\section{JEL Classification $\quad$ M40, M41, G32}

\section{INTRODUCTION}

The phenomenon of earnings management is one of the management practices in order to comply with the rapid changes in the external and internal environment and the ability to survive, grow and compete. It can also be seen as a reflection of the aims and interests of the management rather than as a reflection of the real performance of the company by exploiting the flexibility of the management to choosing between alternative accounting policies within the accepted accounting principles and non-compliance with professional standards and ethical values, as well as a conflict of interests between the management of the company and other parties' interests.

The division of ownership and authority creates agency problems. This argument is consistent with Levitt (1998) who found a significant positive relationship between agency conflicts, and the degree of division between ownership and control. The result in the study shows that as the degree of separation between ownership and power increases, the agency problem and costs increase. Therefore, effective power and observation are needed to reduce agency problems and costs.

According to the agency's theory, the company is seen as a series of contractual relationships between a range of conflicting interests, owners, managers, and creditors. These relationships include delegation of decision-making authorities to management, which may lead 
to many conflicts of interests between management, owners' equity or between management and creditors. This conflict of interests results in a set of problems called agency problems that resulted from each party seeking to maximize its own interests even at the expense of the other's interests (Jensen \& Meckling, 1976).

The ownership structure of the company has raised controversy and debate regarding its role in an effective control of the management behavior and the limitation of earnings management practices, since Siregar and Utama (2008) found that in companies where ownership structures are dispersed among a large number of owners, each has a limited number of shares of the company's capital, the managers there will be in a position to use the methods and means that enable them to achieve their own interests, because there is no incentive for shareholders to closely monitor the company's activities in addition to the weak participation of shareholders in management decisions or policies. Also Aygun et al. (2014) show that in companies with property structures concentrated in the hands of senior owners, they are subjected to oversight and follow-up by these owners, because they have the resources and incentives to monitor the management's behavior and reduce their ability to perform earnings management practices.

The previous studies have found that there is a difference between the results of that examining the effect of the ownership structure on earnings management practices. Therefore, this study is designed to test the effect of ownership structures related to the concentration of ownership, institutional ownership and foreign ownership in influencing and limiting the practices of earnings management in Jordanian industrial companies.

\section{LITERATURE REVIEW}

\subsection{The problem of the study}

The conflict of interests between the various parties related to the company has resulted in the necessity of having many rules and mechanisms that form a framework for monitoring and supervising the behavior of the management to limit problems of the agency, in order to protect the interests of others parties and motivate managers to work on the interests of the shareholders and maximize the value of the company (Jensen \& Meckling, 1976), so this is the reason for the presence of the corporate governance concept.

The owner's role in corporate governance and the effective control of management behavior depends on a key factor related to the company's ownership structure. As Parveen et al. (2016) mentioned, in the case of the distribution of the shares of the company among a large number of shareholders, this will affect their ability to play an effective control role on the management, and their ability to carry out earnings management practices. The previous studies reach to different results related to the effect of ownership structure on earnings management practices; thus, this requires testing the effect in the Jordanian business environment; and trying to identify the effect of ownership structure as one of the mechanisms of corporate governance in reducing the management's ability to conduct opportunistic actions that may maximize its interests even at the expense of other parties' interests.

From what is previously mentioned, the researcher believes that the problem of research is represented in the following main question: What is the effect of ownership structure (concentration ownership, institutional ownership, and foreign ownership) in limiting earnings management practices in industrial companies listed on the Amman Stock Exchange for the period 2012-2016?

\subsection{The significance of the study}

The significance of this study appears from the important issue of earnings management and the effect of ownership structure in limiting opportunistic earnings management practices, which may lead to maximizing interests of the management and has become a subject that has received great attention both domestically and globally in recent times, and its impact on the quality of financial reports, development and confidence of financial 
market, and the ability of the country to attract foreign investments, which contributes to the growth of the national economy and its prosperity.

The scarcity of studies that deal with the variables of the current study in the Arab environment in general and in Jordanian environment in particular requires testing and studying the ownership structure and its effect on the earnings management practices in the Jordanian environment.

\subsection{The contribution of the study}

This study is different from other studies where it is noted that the majority of studies, which examined this subject, have tried to test the effect of the capital structure or ownership structure on performance, especially in the Arab world. Thus, this study is expected to add new conclusions to Arab and foreign studies on the effect of the ownership structure on earnings management practices and increase the fairness and confidence of the financial statements and help the users of financial statements, which determine the financial situation closest to the company's reality. Moreover, most of the studies focus on different service sectors, including the banking sector, so this study attempts to test the effect on the Jordanian industrial sector for the period 2012-2016, which is a recent period that can provide evidence of the effect of the ownership structure on the earnings management practices during the study period.

\subsection{Theoretical framework and hypotheses}

Several studies, including Neffati, Imène, and Christophe (2011), have revealed that earnings management practices have been increasing, particularly in stock companies whose shares are traded on the stock exchange. The management of these companies uses a range of methods to influence financial reports and their items, in particular, the profit figure, taking the advantages of the flexibility of selecting between alternative accounting policies available within the accepted accounting principles. Holland and Ramsay (2003) defined earnings management as multiple management practices in financial measurement and reporting, including all interventions in preparing external financial reporting with the intention of achieving intended gains or goals.
Healy and Wahlen (1999) define earnings management as the administration's use of its own provisions in preparing the financial reporting and the formation of specific transactions with the aim to change financial reports either to mislead some stakeholders with respect to the real performance of the company or to influence the results of contractual arrangements based on the disclosure of accounting numbers.

Siregar and Utama (2008) clarify two types of earnings management: efficient earnings management, which is designed to improve the profits declared in the income statement without taking advantage of its own interests, the second one is opportunistic earnings management, which is carried out by the management in order to report earnings that achieve their interests at the expense of others parties' interests.

Ahmad (2009) classifies ownership structure according to the percentage of share ownership, into dispersion ownership or so-called (outsider ownership), which is applicable to the case of the spread of shares among a large number of shareholders, thereby weakens the ability of owners to control management's behavior. And concentration ownership or so-called insider ownership is in the case that the ownership of the shares is concentrated among a limited number of shareholders. Lei (2012) indicates that the concentration of ownership shall be in case of shareholders whose ownership exceeds $5 \%$ of company shares.

Moreover, Ahmad (2009) divides ownership structure in terms of the identity of the owners to three divisions, the first one is institutional shareholders in case the ownership of shares is concentrated in some investing institutions such as insurance companies and savings and pension funds, so that they become influential and observers of the decisions and actions of the management practices that can be exercised to achieve their purposes. The second one is family owned, where ownership and management focus on the members of a single family, which outlines the general framework of the company through its dominance on the board of directors and development set of controls to monitor the company, and the third one is foreign ownership in the case of owning foreign shareholders, whether other Arab or foreign country, to the shares of the company. Björn (2016) 
defines foreign ownership as the ownership of the investor, whether natural or legal person in the stock exchange market of another country.

The study of both Al-Khayl (2009) and Ali (2011) shows that if ownership is concentrated among a limited number of shareholders, it often increases their ability and motivation to control managers, so that they become influential and observers of management decisions and earnings management practices that could be carried out to achieve their goals.

Zhuang et al. (2000) see some criticisms of dispersion of ownership, including poor shareholders control that results from dispersion, because they bear the costs of supervision, which may be high compared with their shares, and giving managers opportunity to control the companies and trying to achieve their own interests at the expense of others parties' interests.

Al-Khayl (2009) points out that the dispersal of ownership may result in a lack of shareholders incentive to closely monitoring the activities of the company, weak participation in management decisions or policies, and the desire to obtain profits in the short term, then this leads to making decisions that may not result in long-term profits for the company.

Boehmer and Kelley (2009) concluded that if the shares of the company are concentrated in institutions investing such as investment funds companies, insurance companies, and pension funds, in a degree granting them the right to participate effectively in the control of management decisions and practices, thereby reducing agency costs.

Markarian and Bricker (2015) confirm that the institutional investor has the expertise and competence to analyze information and draw conclusions, thereby significantly reducing the management ability to exploiting internal information to achieve their own interests and leading to increased quality of the financial statements. These results are consistent with the study of Koh (2003) who confirms that the concentration of institutional ownership is inversely related to the size of discretionary accruals and artificial profits, which leads to increased earnings quality and thus the quality of financial reports. Moreover, Velury and Jenkins (2006) indicate that institutional investor plays an active role in controlling and monitoring management's discretion, as the presence of institutional investors restricts management from earnings management practice to fulfill their purposes and own interests. The study of Smith (1996) notes that shareholders' proposals at the general assembly meetings usually receive greater care and are put into action faster, as the percentage of institutional ownership in the company increases, which is reflected positively on the financial and operational performance of this company. Velury et al. (2003) also stress that institutional investors often prefer high-quality financial statements, encouraging companies to seek the qualified audit firms to perform their audit activities in high quality.

Velury and Jenkins (2006) note that an institutional investor can control the behavior of the management indirectly by influencing the company's information environment, and also it considers one of the key objectives of corporate governance to increase the quality of the company's financial statements and the information it contains. Moreover, increasing the percentage of institutional ownership in the company's shares leads to timeliness, neutrality and faithful representation of information.

Agrawal and Mandelker (1990) note that companies in which institutional investors have a high proportion of their shares increase their chances to change management as a punishment for poor performance, compared to other companies, where individual's investors have a high proportion of their ownership structure.

Boehmer and Kelley (2009) note that institutional ownership is an important mechanism for reducing agency costs and problems, reducing opportunistic behavior of management, protecting investor interests and assisting in the convergence of interests between management and owners, because they have the motivation and ability to exercise effective and continuous control over the decisions, practices, and behaviors of the management.

Chung et al. (2002) found that a high proportion of the institutional ownership investment of company's shares limits the management's conduct of earnings management practices toward their own interests, and thus the institutional investor helps to improve the effectiveness of corporate governance role. 
Cillian and Patricia (2002) argue that institutional ownership leads to a lower probability of management managing or manipulating earnings to achieve their own interests by controlling the elements and decisions that are dependent on the opinion and personal judgment of management.

The study of Yeo (2002) indicates that the control of blockholders outside the company is similar to the control of institutional ownership on earnings management practices.

Dechow et al. (1996) state that blockholders outside the company have the motivation and ability to control business and management behavior more than small shareholders, which may result in reducing earnings management practices through good management control and monitoring. Filatotchev and Nakajima (2010) suggest that an increase in the blockholders may result in the so-called "entrenchment problem", created by the possibility that blockholders can use their influence to acquire minority rights by doing practices and making investment decisions serve their own interests.

Al-Fayoumi et al. (2010) aim to examine the impact of institutional ownership and blockholders ownership in limiting the earnings management practices of Jordanian companies operating in emerging markets. The study found that there is no significant effect of institutional ownership and blockholders ownership in limiting earnings management practices. The study attributes this result to the lack of sufficient experience of the institutional and blockholders of Jordanian companies operating in emerging markets. The Mitani (2010) study finds that earnings management practices are limited in companies whose ownership structure is characterized by institutional ownership investment and ownership concentrated in the hands of blockholders.

Alwshah (2009) finds that the presence of foreign ownership in the shares of companies often leads to improved company's performance, due to the improvement of the control and supervision of the company's management, so that the foreign ownership strengthens the local companies with foreign shareholders who are working to develop and enhance the means of corporate governance effec- tively, for example, by becoming members of the board of directors, as well as merging the emerging markets in the developing countries with the global economy markets. Phung (2015) states that the presence of foreign ownership in the company may lead to transfer of modern technology and management skills, in addition to supervisory roles exercised by foreign owners, will reduce the agency's problems in the company. Also, foreign owners are interested in disclosure and perform best accounting practices, in turn, improving the quality of financial reports. Choi et al. (2012) found that the presence of foreign ownership at high proportion may lead to the exploitation of foreign owners' authorities to influence the administrative decisions in a manner that achieves their own interests, therefore, affecting the performance of the company negatively.

Khamis et al. (2015) attribute the negative relationship between foreign ownership and management performance to the far distance and insufficient accounting disclosures, which weakens the ability of foreign owners to monitor the performance and behavior of the company's management. The study by Harb (2015) found that there is a positive effect of foreign ownership (non-Jordanians) on the performance of Jordanian banks, while institutional ownership affects the performance of Jordanian banks negatively.

Finally, after the mentioned above previous background studies, this study came to test the effect of ownership structure in the light of the debt ratio and company size as controlling variables in limiting the earnings management practices of the Jordanian industrial companies for the period 2012-2016. Thus, the following hypotheses are tested in this study:

- there is no significant effect of the concentration ownership on earnings management practices of Jordanian industrial companies;

- there is no significant effect of the institutional ownership on earnings management practices of Jordanian industrial companies;

- there is no significant effect of the foreign ownership on earnings management practices of Jordanian industrial companies. 


\section{RESEARCH METHODOLOGY}

\subsection{Study population and sample}

The study population is composed of all industrial companies listed on the Amman Stock Exchange, which reached 63 companies at the end of 2016 according to the directory of companies issued by the Amman Stock Exchange. The sample of the study which consisted of 55 industrial companies that met the conditions of the study were: To be a Jordanian industrial company listed on the Amman Stock Exchange, the annual reports of the company during the period 2012-2016, and all necessary data about the company to calculate the variables of the study during the period 2012-2016 must be available.

\subsection{Measurement of the study variables}

The dependent, independent and controlled variables of the study were measured as follows:

\section{- The dependent variable (earnings management).}

This study examined the effect of the ownership structure on earnings management, which was considered the dependent variable in this study. The Jones model, modified by Dechow et al. (1995), was used to measure earnings management practices, which is a commonly used model for measuring earnings management practices. It is also called discretionary accruals method, where the total accruals consist of discretionary and nondiscretionary accruals.

The cash flow method used to measure annual total accruals of the study sample, which is 55 companies during the study period (2012-2016), is presented through the equation:

$$
T A C C_{i, t}=N O P_{i, t}-O C F_{i, t},
$$

where $T A C C_{i, t}$ - the total accruals consisting of discretionary and non-discretionary accruals, $N O P_{i, t}$ - net operating profit, $O C F_{i, t}$ - operating cash flows, $i, t$ refer to year for firm $i$.
Calculation of non-discretionary accruals for each company through the equation:

$$
\begin{aligned}
& N D A C C_{i, t}=a_{1}\left(\frac{1}{A_{i, t-1}}\right)+ \\
& +a_{2}\left(\Delta R E V_{i, t}-\Delta R E C_{i, t}\right)+a_{3}\left(P P E_{i, t}\right) .
\end{aligned}
$$

Estimating the parameters of the above equation by using regression model through the following equation:

$$
\begin{aligned}
& \frac{T A C C_{i, t}}{A_{i, t}}=a_{1} \frac{1}{A_{i, t-1}}+ \\
& +a_{2} \frac{\Delta R E V_{i, t}-\Delta R E C_{i, t}}{A_{i, t-1}}+a_{3} \frac{P P E_{i, t}}{A_{i, t-1}}+E_{i, t},
\end{aligned}
$$

where $N D A C C$ - non-discretionary accruals, $T A C C$ - total accruals, $A$ - total assets, $\triangle R E V$ - changes in revenues, $\triangle R E C$ - changes in accounts receivables, $P P E$ - property plant and equipment, $a_{1}, a_{2}, a_{3}$ - parameters of the model regression equation, $E_{i, t}$ - estimated error of regression equation, $i, t$ refer to year for firm $i$.

- Calculation of the discretionary accruals for each company within the sample of the study through the difference between the total accruals and the non-discretionary accruals as in the equation:

$$
D A C C_{i, t}=T A C C_{i, t}-N D A C C_{i, t},
$$

where $D A C C$ - the discretionary accruals for each company in year $t$ for firm $i$.

The earning management practice is judged by the remaining value between absolute value of the discretionary accruals - average absolute value of the discretionary accruals for each company during the study period 2012-2016, so that the positive value indicates earnings management practice and the negative value indicates no earnings management practice.

Independent variables related to the ownership structure include:

concentration ownership: measured by shareholders owning more than $5 \%$ of the total 
number of the shares issued and traded in the stock exchange market for each company (Lei, 2012);

- institutional ownership: measured by the number of shares owned by the institutions - non-individuals - relative to the total number of issued and traded shares in the stock exchange market for each company (Hamdan et al., 2012);

- foreign ownership (non-Jordanian): it was measured by the number of shares owned by Arab and non-Arab foreign shareholders (nonJordanians) relative to the total number of issued and traded shares in the stock exchange market for each company (Lei, 2012);

- control variables of the study;

- debt ratio was calculated by dividing total liabilities by total assets (Shehu \& Jibril, 2012);

- company size: measured by the natural logarithm of total assets (Warokka, 2014).

\section{EMPIRICAL RESULTS AND DISCUSSION}

\subsection{Data analysis}

The study used SPSS Statistics version 22 to examine the validation of the data for the regression model, and test the hypotheses of the study, using panel data, which included both time series data and cross-section data.
Table 1 shows the validation tests of the study data according to the regression model.

Referring to Table 1, the data can, therefore, be asn sumed to be normally distributed, since the number of observations in the study is 213 and, according to the Central Limit Theory, the normal distribution condition of large samples $(n>30)$ can be assumed (Johnson, 2004).

Table 1 indicates the value of Variance Inflation Factor (VIF) is less than 10 for each independent variable. Thus, it is clear that there is no multicollinearity between the independent variables of the study; therefore, the level of variance in each independent variable of study is accepted. Also, Table 1 shows that the D-W test value between standard error of the estimate limits in the regression model was limited between 0 and 4 , which indicates that the study data are free from autocorrelation problem.

The Hausman test was used to decide whether fixed or random effects model would be more appropriate in the regression model. Since $\left(\mathrm{ch}^{2}\right)$ in the Table 1 was greater than $5 \%$ the random effect of the regression model should be used.

\subsection{Descriptive statistics of the study variables}

This subsection presents the descriptive statistics for study variables, based on annual financial reports issued by the Jordanian industrial companies, for the period 2012-2016, as shown in Table 2.

We note, in Table 2, the mean of the earnings management (residual values) divided by total assets of

Table 1. Relevance of study data according to regression tests

Source: Result output from SPPS statistic analysis.

\begin{tabular}{|c|c|}
\hline Variables & Value \\
\hline VIF (concentration ownership) & 2.011 \\
\hline VIF (institutional ownership) & 3.123 \\
\hline VIF (foreign ownership) & 2.601 \\
\hline VIF (debt ratio) & 4.564 \\
\hline VIF (total asset) & 3.778 \\
\hline D-W test & 1.999 \\
\hline $\mathrm{ch}^{2}$ & 4.6562 \\
\hline Sig $\left(\mathrm{ch}^{2}\right)$ & 0.4592 \\
\hline No. of observations & 251 \\
\hline
\end{tabular}


Table 2. Descriptive statistics for study variables

Source: Result output from SPPS statistic analysis.

\begin{tabular}{|c|c|c|c|c|c|}
\hline Study variables & $\mathbf{N}$ & Minimum & Maximum & Mean & Std. deviation \\
\hline Earnings management ratio & 251 & -1.5409 & 0.0023 & 0.0012 & 0.0042 \\
\hline Concentration ownership ratio & 251 & 0.000 & 1.0000 & 0.6531 & 0.2471 \\
\hline Institutional ownership ratio & 251 & 0.000 & 0.9949 & 0.4915 & 0.2905 \\
\hline Foreign ownership ratio & 251 & 0.000 & 0.9864 & 0.2034 & 0.2507 \\
\hline Debt ratio & 251 & 0.004 & 1.295 & 0.3756 & 0.2087 \\
\hline Total assets & 251 & 1195002 & 1211577000 & 69579402 & 191800800 \\
\hline Valid N (listwise) & 251 & - & - & - & - \\
\hline
\end{tabular}

the company during the period 2012-2016 in the Jordanian industrial companies was 0.0012 . This positive value explains the use of discretionary accruals by Jordanian industrial companies in a positive manner to exercise earning management practices. Through the value of standard deviation, it shows variances in earnings management practices by Jordanian industrial companies.

The arithmetic mean of concentration ownership, institutional ownership and foreign ownership ratios - divided by total assets - were $65 \%, 49 \%$ and $20 \%$, respectively, during the period from 2012 to 2016. This indicates that the proportion of concentration ownership is relatively high, compared with the percentage of institutional ownership and foreign ownership. While the standard deviation of the concentration ownership, institutional ownership, and foreign ownership during the period 20122016 were $25 \%, 29 \%$ and $25 \%$, respectively, it indicates the different ownership structure ratios in the industrial companies listed on the Amman Stock Exchange. Also it indicates that the majority of the investments are related to Jordanian investments, explaining it by the low percentage of foreign investment in Jordanian Stock Exchange.

Also Table 2 shows the arithmetic mean of the debt ratio and the size of the company divided by the total assets during the period from 2012 to 2016 were $38 \%$ and 69579402 , respectively, with a standard deviation of $21 \%$ and 191800800 , respectively. This indicates the degree of dependence on debt funds, as a source of finance differs between Jordanian industrial companies and the variances of the industrial companies' size represented by total assets, indicates differences on their ability to achieve profits and obtain funding from different sources.

\subsection{Testing the hypotheses of the study}

The model of the study was modeled as a regression equation to test the effect of the independent variables (ownership structure) in the light of the control variables (the debt and the logarithm of the total assets) on the dependent variable (earnings management), which was as follows:

$$
\begin{aligned}
& E M_{i, t}=\alpha_{0}+B_{1} C O_{i, t}+B_{2} I O_{i, t}+ \\
& +B_{3} F O_{i, t}+B_{4} D R_{i, t}+B_{5} \log A s+e_{i, t} .
\end{aligned}
$$

where dependent variable - EM (earnings management), independent variables - $C O$ (concentration ownership), $I O$ (institutional ownership), $F O$ (foreign ownership), controls variables - $D R$ (debt ratio), $\log A s$ (natural $\log$ of total asset), $\alpha_{0}$ - constant, $B_{1}-B_{2} \ldots B_{5}$ - regression coefficient, $e_{i, t}$ - error of the estimate.

The results of multiple regression models are shown in Table 3.

Table 3 shows that the explanatory factor $\left(R^{2}\right)$ for the independent and control variables accounts for $38 \%$ of the change in the earnings management of the Jordanian industrial companies assuming other factors remaining stable. The value of $F$ was 10.63 , which is statistically significant, meaning that the percentage of change in $R^{2}$ and regression model were statistically significant at $\alpha \leq 0.05$.

By reference to the coefficients of independent variables in Table 3 , it has been shown that there is a significant negative effect of concentration ownership on the earnings management, where the value of $t$ was 3.651 at a significant level Sig $=0.00$. Therefore, the alternative hypothesis is accepted, 
Table 3. Regression results (effect of financial structure on earnings management)

Source: Result output from SPPS statistic analysis.

\begin{tabular}{|c|c|c|c|c|c|}
\hline \multirow{2}{*}{ Study variables } & $\begin{array}{c}\text { Unstandardized } \\
\text { coefficients }\end{array}$ & \multirow{2}{*}{ Std. error } & $\begin{array}{c}\text { Standardized } \\
\text { coefficients }\end{array}$ & \multirow[t]{2}{*}{$\mathbf{T}$} & \multirow{2}{*}{ Sig. } \\
\hline & B & & Beta & & \\
\hline Constant & 0.232 & 0.076 & - & 2.39 & 0.025 \\
\hline CO (concentration ownership) & -0.141 & 0.034 & -0.261 & -3.651 & 0.000 \\
\hline IO (institutional ownership) & -0.070 & 0.022 & -0.132 & -1.601 & 0.111 \\
\hline FO (foreign ownership) & 0.042 & 0.038 & 0.098 & 1.234 & 0.211 \\
\hline DR (debt ratio) & 0.154 & 0.065 & 0.341 & 4.523 & 0.000 \\
\hline LogAs (natural log of total asset) & 0.057 & 0.011 & 0.312 & 2.734 & 0.006 \\
\hline \multirow{2}{*}{ Regression model summary } & \multicolumn{2}{|c|}{$\left(R^{2}\right)=0.38$} & \multicolumn{3}{|c|}{ Adjusted $\left(\mathrm{R}^{2}\right)=0.33$} \\
\hline & \multicolumn{2}{|c|}{$F=10.63$} & \multicolumn{3}{|c|}{ Sig F. $=0.00$} \\
\hline
\end{tabular}

$$
E M_{i, t}=\alpha_{0}+B_{1} C O_{i, t}+B_{2} I O_{i, t}+B_{3} F O_{i, t}+B_{4} D R_{i, t}+B_{5} \log A s+e_{i}
$$

which states that "there is a significant effect of the concentration ownership on the earnings management practices of Jordanian industrial companies".

This reflects the opposite effect of the concentration ownership in the Jordanian industrial companies on earnings management practices. This finding agrees with the result of the studies of Zhuang et al. (2000), Ali (2011), Alikhial2009)) who show a statistically significant adverse effect of the concentration ownership on earnings management practices. Other studies such as Yang et al. (2009), Al-Fayoumi et al. (2010), Siregar and Utama (2008), Filatotchev and Nakajima (2010) have found that there is no effect of concentration ownership on earnings management practices or that it may increase the likelihood of conducting earnings management practices.

The results in Table 3 show that the significant values of the institutional and foreign ownership on the earnings management practices are 0.11 and 0.21 , respectively, which confirms that there is no significant effect at the significance level $\alpha \leq 5 \%$ for institutional ownership and foreign ownership on the earnings management practices of Jordanian industrial companies. Therefore, the null hypothesis is accepted that states: "There is no significant effect of institutional ownership on the earnings management practices of Jordanian industrial companies". This finding is consistent with the study of Al-Fayoumi et al. (2010), which concludes that there is no effect of institutional ownership in limiting earnings management practices, and differs with the results of the studies of Chung et al. (2002), Koh (2003), Markarian and Bricker (2015), Boehmer and Kelley (2009), Mitani (2010) who show the institutional ownership limits earnings management practices. Also, the study accepts the null hypothesis, which states that "there is no significant effect of foreign ownership on the earnings management practices of Jordanian industrial companies", this finding agrees with Khamis et al. (2015) who show that foreign ownership doesn't limit the earnings management practices for the distance and insufficient accounting disclosures of the company. And it also disagrees with the study of Alwshah (2009) and Phung (2015) who show that foreign ownership limits the earnings management by effectively developing corporate governance role.

Table 3 shows that the debt and the size of the company measured by the natural logarithm of the total assets positively affect the earnings management of the Jordanian industrial companies listed on the Amman Stock Exchange, where the significant values were 0.000 and 0.006 , respectively. This indicates that the high debt ratio and the high value of the company's assets increase the opportunity for the Jordanian industrial companies' management to carry out earnings management practices. This result is consistent with the results of the study of Ramadan (2013), which confirms that the size of the company's assets affects the management's tendency towards earnings management practices. It also agrees with the results of Tahir et al.'s (2011) study, which 
confirms that the company's indebtedness affects the discretionary accruals and, thus, the earnings management practices, and differs with Al-Beri's (2011) study, which proves the absence of a significant effect of the company size measured by total assets on earnings management practices, and also differs with the study of Abujabh (2015), which shows that debt ratio and the size of the company have no significant effect on earnings management practices.

\section{CONCLUSION}

The study reached the major following conclusions:

1. There is an indicator of earnings management practice in the Jordanian industrial companies, where it was found that the average of the earnings management (residual values) reached 0.0012 , depending on the Jones model modified by Dechow et al. (1995), so this positive value is explained in using discretionary accruals by the Jordanian industrial companies in a positive manner for carrying out the earnings management practices.

2. It was found that the ownership structure (concentration, institutional and foreign ownership) in the light of the control variables (debt ratio and company size) explained for $38 \%$ of the variances in the earnings management practices of Jordanian industrial companies listed on the Amman Stock Exchange, which can be seen as an indicator of the importance of ownership structure in influencing earnings management practices.

3. The significant effect of concentration ownership in the limitation of earnings management practices in Jordanian industrial companies may be attributed to the possession of authority and incentives among shareholders who have a high proportion of the company's shares, to control the management and activate the mechanisms of corporate governance and limit the opportunities available to the management for exercise earnings management practices, and it will be more easy for many shareholders who have a high proportion of the company's shares to coordinate their work and obtain information from managers to assess their performance. Also, it is possible to increase the percentage of independent managers on the board of directors, and therefore improve their performance and protect minority rights and company's resources.

4. There is no significant influence of institutional ownership and foreign ownership on limiting the earnings management practices in Jordanian industrial companies, which may be attributed from the researcher's point of view that Jordanian institutional investor does not have sufficient experience to limit the earnings management practices, or that they are accompanied with the management in order to achieve personal interests at the expense of other parties' interests, in addition to the inability of the Jordanian industrial companies to encourage institutional and foreign investors to invest in their shares in sufficient proportions that may lead them to follow up and control the performance of the management.

In light of the study conclusions, the researcher recommends that the Securities Commission in the Amman Stock Exchange should oblige Jordanian industrial companies to disclose their ownership ratios in a manner that encourages institutions and block investors to invest in these companies and increase their supervisory role to limit the earnings management practices, especially Jordanian companies operating in an environment controlled and dominated by the company's management, which has a strong motivation and a great opportunity to conduct earnings management practices to maximize their interests at the expense of the minority interests. Moreover, this increases the attention of the government in the development of laws and legislation that encourage and attract foreign investment and open their markets to foreign trade and investment, this leads to an increase in the percentage of 
foreign ownership in the Jordanian companies, expected to have a positive reflection on the improvement of companies' performance and limitation of the earnings management practices. In addition, the researcher recommends that the external auditors increase their attention in the examination of discretionary accruals and contain their reports on a paragraph confirming that the audited financial statements are free from misleading earnings management practices, and also recommends conducting further studies on the effect of ownership structure on other variables and sectors not covered by this study.

\section{ACKNOWLEDGMENT}

The author is grateful to the Middle East University, Amman, Jordan for the financial support granted to cover the publication fee of this research article.

\section{REFERENCES}

1. Abujabh, Awni (2015). The effect of profitability on earnings management in Jordanian Industrial Companies listed on the Amman Stock Exchange (Master Thesis). Zarqa University, Jordan.

2. Agrawal, A., \& Mandelker, G. (1990). Large shareholders and the monitoring of managers: The Case of Antitakeover Charter Amendments. Journal of Financial and Quantitative Analysis, 25(2), 143-161. https:// doi.org/10.2307/2330821

3. Ahmad, Mohieddin (2009). The effect of ownership structure and control on accounting disclosure companies - applied analytical study (Doctoral Thesis). Alexandria University, Egypt.

4. Al-Beri, Mohammad (2011). The effect of quality accounting disclosure on earnings management (Master Thesis). Applied Science University, Jordan.

5. Al-Fayoumi, N., Abuzayed, B., \& Alexander, D. (2010). Ownership structure and earnings management in emerging markets: The case of Jordan. International Research Journal of Finance and Economics, 38(1), 28-47. Retrieved from https://www.researchgate. net/publication/228642167_Ownership_Structure_and_Earnings_ Management_in_Emerging_Markets_The_Case_of_Jordan

6. Ali, Ahmed (2011). Evaluation the differences effect in corporate ownership structure on the earnings quality of financial reports
- Applied study (Master Thesis).

Helwan University, Egypt.

7. Alikhial, Tawfiq (2009). The effect of governance mechanisms on the financial performance of Saudi companies. Journal of Ain Shams University, 2(1), 192-222. Retrieved from https://search.mandumah. com/Record/109266

8. Alwshah, K. A. A. M. (2009). The impact of corporate governance and ownership structure on performance and financial decisions of firms: evidence from Jordan (Doctoral Dissertation). University of Hull. Retrieved from http://hydra.hull. ac.uk/resources/hull:6971

9. Aygun, Mehmet, Suleyman, Ic, \& Sayim, Mustafa (2014). The effects of corporate ownership structure and board size on earnings management: evidence from Turkey. International Journal of Business and Management, 9(12), 123-133. http://dx.doi. org/10.5539/ijbm.v9n12p123

10. Björn, L. (2016). Ownership structure's effect on dividend policy (Master thesis). Umeå University. Retrieved from http://urn.kb.se/ resolve?urn=urn:nbn:se:umu:di va-123941

11. Boehmer, E., \& Kelley, E. (2009). Institutional investors and the informational efficiency of prices. The Review of Financial Studies, 22(9), 3563-3594. https://doi. org/10.1093/rfs/hhp028

12. Choi, H. M., Sul, W., \& Min, S. K. (2012). Foreign board membership and firm value in Korea. Management Decision, 50(2), 207-233. https://doi. org/10.1108/00251741211203533

13. Chung, R., Firth, M., \& Kim, J. (2002). Institutional monitoring and opportunistic earnings management. Journal of Corporate Finance, 8(1), 29-48. https://doi.org/10.1016/S09291199(01)00039-6

14. Dechow, P., Sloan, R., \& Sweeney, A. (1995). Detecting earnings management. The Accounting Review, 70(2), 193-225. Retrieved from https://www.jstor.org/ stable/248303

15. Dechow, Patricia M., Sloan, Richard G., Sweeney, \& Amy, P. (1996). Causes and consequences of earnings manipulation: An analysis of firms subject to enforcement actions by the SEC. Contemporary Accounting Research, 13(1), 1-36. https://doi. org/10.1111/j.1911-3846.1996. tb00489.x

16. Filatotchev, I., \& Nakajima, C. (2010). Internal and external corporate governance: An interface an organization and its environment. British Journal of Management, 21(3), 591-606. https://doi.org/10.1111/j.14678551.2010.00712.x

17. Hamdan, Allam, Anaswa, Mohammed, \& Al-Otaibi, Mahmoud (2012). The effect of the ownership structure on the level of investment in information 
technology and its effect on the performance of Jordanian Banks: An analytical study for the period 2003-2008. Journal of the Islamic University for Economic and Administrative Studies, 20(2), 381-416. Retrieved from http:// journals.iugaza.edu.ps/index.php/ IUGJEB/article/view/408.

18. Harb, Heba (2015). The impact of ownership structure on performance: An empirical study on Jordanian Banks (Master's Thesis). Yarmouk University, Jordan.

19. Healy, P. M., \& Wahlen, J. M. (1999). A review of the earnings management literature and its implications for standard setting. Accounting Horizons, 13(4), 365383. https://doi.org/10.2308/ acch.1999.13.4.365

20. Holland, David, \& Ramsay, Alan (2003). Do Australian companies manage earnings to meet simple earnings benchmarks? Accounting and Finance, 43(1), 41-62. https:// doi.org/10.1111/1467-629X.00082

21. Jensen, M., \& Meckling, W. (1976). Theory of the firm: managerial behavior, agency cost, and ownership structure. Journal of Financial Economics, 3(1), 305360. https://doi.org/10.1016/0304405X(76)90026-X

22. Johnson, O. T. (2004). Information theory and the central limit theorem (1st ed.). World Scientific, London.

23. Jordan Securities Commission, Amman Stock Exchange. Retrieved from https://jordan.gov. jo/wps/portal/Home/OpenDataMain/OpenDataUser/?lang=ar\&is FromLangChange=yes\#/manageDataSets

24. Khamis, Reem, Hamdan, Allam, \& Elali, Wajeeh (2015). The relationship between ownership structure dimensions and corporate performance: Evidence from Bahrain. Australasian Accounting, Business, and Finance Journal, 9(4), 38-56. http://dx.doi. org/10.14453/aabf.v9i4.4

25. Koh, P. (2003). On the association between institutional ownership and aggressive corporate earnings management in Australia. The
British Accounting Review, 35(2), 105-128. Retrieved from http:// hdl.handle.net/1783.1/52949

26. Lei, D. Y. (2012). Privatization ownership structure and performance of China listed companies in split share structure reform (Master Thesis). University of Maryland University College. Retrieved from http://pqdtopen.proquest. com/\#viewpdf?dispub=3494547

27. Levitt, A. (1998). The importance of high quality accounting standards. Accounting Horizons, 12(1), 79-82. Retrieved from https://www.econbiz.de/Record/ the-importance-of-high-qualityaccounting-standards-levitt-arthur/10007064835

28. Markarian, E., \& Bricker, R. (2015). Institutional investors and insider trading profitability. European Accounting Review, 24(3), 495-518. https://doi.org/10. 1080/09638180.2015.1040045

29. Mitani, H. (2010). Additional evidence on earnings management and corporate governance. FSA Research Review, 6, 1-25. Retrieved from https:// www.fsa.go.jp/frtc/seika/discussion/2009/20100203-2.pdf

30. Parveen, Shagufta, Malik, Nazish, \& Mahmood, Yasir (2016). Impact of ownership structure on earnings management: evidence from Pakistani banking sector. Journal of Poverty Investment and Development, 23, 24-35. Retrieved from https://www.iiste.org/ Journals/index.php/JPID/article/ view/30211

31. Phung, D. N. (2015). Ownership structure, corporate diversification, and firm performance: a study of listed firms in Vietnam (Master Thesis). University of Western Sydney. Retrieved from http:// handle.uws.edu.au:8081/1959.7/ uws:32619

32. Ramadan, Ziad (2013). The effect of company size on the practice of earnings management. Journal of Arab Islamic Sciences, Kuwait University, 20(3), 209-260. Retrieved from http://pubcouncil. kuniv.edu.kw/ajas/homear.aspx?id $=8 \&$ Root $=$ yes $\&$ authid $=926 \#$.
33. Shehu, Usman, \& Jibril, Yero (2012). Ownership concentration and earnings management practice of Nigerian listed conglomerates. American International Journal of Contemporary Research, 2(7), 157-164. Retrieved from http:// www.aijcrnet.com/journals/ Vol_2_No_7_July_2012/19.pdf

34. Siregar, S., \& Utama, S. (2008). Type of earnings management and the effect of ownership structure, firm size, and corporate-governance practices: evidence from Indonesia. The International Journal of Accounting, 43(1), 1-27. Retrieved from https://econpapers.repec. org/RePEc:eee:accoun:v:43:y:200 8:i:1:p:1-27.

35. Smith, M. (1996). Shareholder activism by institutional investors: evidence from Calpers. Journal of Finance, 51(1), 227-252. https:// doi.org/10.1111/j.1540-6261.1996. tb05208.x

36. Tahir, S. H., Sabir, H. M., \& Ali, S. Z. (2011). Impact of earnings management on the capital structure of nonfinancial companies listed on (KSE) Pakistan. Global Business and Management Research: An International Journal, 3(1), 96-105. Retrieved from https://trove.nla. gov.au/work/152925504

37. Velury, U., \& Jenkins, D. (2006). Institutional ownership and the quality of earnings. Journal of Business Research, 59(9), 10431051. Retrieved from https:// ideas.repec.org/a/eee/jbrese/ v59y2006i9p1043-1051.html_

38. Velury, U., Reisch, J., \& O'Reilly, D. (2003). Institutional ownership and the selection of industry specialist auditors. Review of Quantitative Finance and Accounting, 21(1), 35-48. Retrieved from https://link. springer.com/article/10.1023 /A:1024855605207

39. Warokka, A. (2014). Ownership structures, capital structure, and firm performance: An analysis of Post East Asian financial crisis (Master Thesis). TDX. Retrieved from http://hdl.handle. net/10486/1894 
40. Yang, W., Chun, L., \& RamadiLi, S. (2009). The effect of board structure and institutional ownership structure on earnings management. International Journal of Economics and Management, 3(2), 332-353. Retrieved from https://www. researchgate.net/publication/287423233_The_effect_of board_structure_and_institutional_ownership_structure_on_ earnings_management
41. Yeo, Gillian H. H., Tan, Patricia M. S., Ho, Kim Wai \& Chen, Sheng-Syan. (2002). Corporate ownership structure and the in formativeness of earnings. Journal of Business Finance and Accounting, 29(7-8), 1023-1046. https://doi. org/10.1111/1468-5957.00460

42. Zhuang, Juzhong, Edwards, David, Webb, David C., \& Capulong, Ma. Virginita (2000). Corporate governance and finance in East Asia a Study of Indonesia, Republic of Korea, Malaysia,
Philippines, and Thailand. Asian Development Bank, 1(1). Retrieved from http://eprints.lse. ac.uk/id/eprint/39403

43. Zhong, K., Donald, W., \& Zheng, X. (2007). The effect of monitoring by outside block holders on earnings management. Quarterly Journal of Business \& Economics, 46(1), 37-60.

Retrieved from https://www.jstor. org/stable/40473429? seq=1\#page_ scan_tab_contents_ 